\title{
CURRENT LITERATURE ON HUMAN MEMORY, LEARNING, AND THINKING
}

Citations of current literature are arranged in outline form so that readers may easily find the particular articles in which they are interested. The literature on Human Experimental Psychology is divided into two parts, with each part appearing in alternate months. The part covered here consists of Human Memory, Learning, and Thinking. The part to be published next month will consist of citations on Perception, Performance, and Experimental Social Psychology. The principal headings used are given on the cover along with page references.

\section{HUMAN LEARNING}

ATKINSON, R. C. (Stanford Univ., Stanford, Calif. 94305), \& PAULSON, J. A. An approach to the psychology of instruction. Psychological Bulletin, 1972, 78, 49-61.

CRAIG, C. S. (Mechanized Info. Ctr., Ohio State Univ., Columbus, Ohio 43210), STERNTHAL, B., \& OLSHAN, $K$. The effect of overlearning on retention. Journal of General Psychology, 1972, 87, 85-94.

JOHNSON, R. E. (SCC “G," Purdue University, Lafayette, Ind. 47907). Associative labeling and retention. Psychological Record, 1972, 22, 237-239.

LEIBRECHT, B. C. (U.S. Army Med. Rsch. Lab., Ft. Knox, Ky. 40121). Habituation, 1940-1970: Bibliography and key word index. Ps y chonomic Monograph Supplements, 1972, 4(11, Whole No. 59).

McDOWELL, A. A. (Moorhead State Coll., Moorhead, Minn. 56560). Two-trial learning set formations by college students. Journal of General Psychology, 1972, 87, 95-98.

\section{CONDITIONING}

BUSTINOVÁ, L. (Pedagogical Faculty J. A. Komenský Univ., Trnava, C z e choslovakia). Verbal conditioning in simple and paranoid forms of schizophrenia. Studia Psychologica, XIV, 1972, 2, 183-185.

GENDREAU, P. (Trent Univ., Peterborough, Ont., Canada), SHERLOCK, D., PARSONS, T., MCLEAN, R., SCOTT, G. D., \& SUBOSKI, M. D. Effects of methaphetamine on well-practiced discrimination conditioning of the eyelid response. Psychopharmacologia (Berlin), 1972, 25, 112-116.

JELÍNKOVÁ, Z. (Czechoslovak Acad. of Sci., Prague, Czechoslovakia). Conditioning and differentiation during sleep. Studia Psychologica, XIV, 1972, 2, 109-114.

KONECNI, V. J. (Univ. of Toronto, Toronto 181, Ont., Canada), \& SLAMECKA, N. J. Awareness in verbal nonoperant conditioning: An approach through dichotic listening. Journal of Experimental Psychology, 1972, 94, 248-254.

REMINGTON, R. E. (Univ. of Exeter, Exeter, England), \& STRONGMAN, K. T. Operant facilitation during a pre-reward stimulus: Differential effects in human subjects. British Journal of Psychology, 1972, 63, 237-242.

SUBOSKI, M. D. (Queen's Univ., Kingston, Ont., Canada), \& LITNER, J. Partial reinforcement and instructional set in discrimination conditioning of the eyelid response. Canadian Journal of Psychology, 1972, 26, 117-126.

\section{DISCRIMINATION}

CROLL, W. L. (Univ. of Iowa, Iowa City, Iowa 52240), \& DUKE, A. W. Evaluation of the posttraining generalization test procedure for measuring amount of learning. Psychonomic Science, 1972, 27, 325-326.

CRONIN, V. (State Univ. of New York, Upstate Med. Ctr., Syracuse, N.Y. 13210). Orientation and position effects of mirror-image reversal discrimination of triangles by young children. Perceptual \& Motor Skills, 1972, 34, 707-711.

GESHURI, Y. (Northwest Missouri State Coll., Maryville, Mo. 64468). Observational learning: Effects of observed reward and response patterns. Journal of Educational Psychology, 1972, 63, 374-380.

JENNESS, D. (Soc. Sci. Rsch. Council, 230 Park Ave., New York, N.Y. 10017). Auditory evoked-response differentiation with discrimination learning in humans. Journal of Comparative \& Physiological Psychology, 1972, 80, 75-90.

ROTHBERG, C. (Dept. of Ed. Fdtns., Univ. of New Mexico, Albuquerque, N. Mex. 87106), \& HARRIS, M. B. " Right,", "wrong,", and discrimination learning in children. Journal of Genetic Psychology, 1972, 120, 275-286.

SWENSSON, R. G. (Bell Tel. Labs., Holmdel, N.Y. 07733). The elusive tradeoff: Speed vs accuracy in visual discrimination tasks. Perception \&
Psychophysics, 1972, 12, 16-32.

THOMSON, W. J. (Vanderbilt Univ., Nashville, Tenn. 37203 ), \& SKVARCIUS, R. Pattern versus component discrimination learning with extended training. Journal of Experimental Psychology, 1972, 94, 233-235.

\section{VERBAL LEARNING}

BOWEN, J. H. (State Univ. of New York, Albany, N.Y. 12203). Frequency stability of Kent-Rosanoff words. Psychological Reports, 1972, 30, 741-742.

HALL, J. W. (Northwestern Univ., Evanston, Ill. 60201). Verbal behavior as a function of amount of schooling. American Journal of Psychology, 1972, 85, 277-290.

KONECNI, V. J. (Univ. of Toronto, Toronto 181, Ont., Canada), \& SLAMECKA, N. J. Awareness in verbal nonoperant conditioning: An approach through dichotic listening. Journal of Experimental Psychology, 1972, 94, 248-254.

WILKES, A. L. (Dundee Univ., Dundee DD1 4HN, Scotland) Reading pauses during serial list learning with fixed or randomly changing groups. Journal of Experimental Psychology, 1972, 94, 206-209.

WYANT, S., BANKS, W. P. (Pomona Coll., Claremont, Calif. 91711), BERGER, D., \& WRIGHT, P. W. Verbal and pictorial similarity in recognition of pictures. Perception \& Psychophysics, 1972, 12, 151-153.

Paired-Associate Learning

BERRY, F. M. (Univ. of Alabama, University, Ala. 35486 ), JOUBERT, C. E., \& BAUMEISTER, A. A. Single-letter selection in paired-associate learning by retardates as a function of degree of learning. Journal of General Psychology, 1972, 87, 145-146.

LEY, R. (State Univ. of New York, Albany, N.Y. 12203), \& LOCASCIO, D. Study time, recall time, meaningfulness, and recognition latency in paired-associate learning. Psychonomic Science, 1972, 28, 88-90.

MAUS, M. (Univ. of Iowa, Iowa City, Iowa 52240). Transfer in the 
A-B ${ }^{\prime}, A-B$ paradigm as a function of anticipation-interval length. American Journal of Psychology, 1972, 85, 217-226.

MONTY, R. A. (Behav. Rsch. Lab., Human Eng. Labs., Aberdeen Proving Ground, Md. 21005), \& PERLMUTER, L. C. The role of choice in learning as a function of meaning and between- and within-subjects designs. Journal of Experimental Psychology, 1972, 94, 235.238.

PFAFFLIN, S. M. (Bell Tel. Labs, Murray Hill, N.J. 07974). An investigation of the effect of two types of sentence contexts on paired-associate learning. Psychonomic Science, 1972, 28, 83-84.

SIEGEL, J. A. (Univ. of Western Ontario, London, Ont., Canada), \& SIEGEL, W. Absolute judgment and paired-associate learning: Kissing cousins or identical twins? Psychological Review, 1972, 79, 300-316.

SILVERSTEIN, A. (Univ. of Rhode Island, Kingston, R.I. 02881). The role of task anxiety in removing the effects of acquired pleasantness in paired-associate learning. Journal of Experimental Psychology, 1972, 94, 173-178.

SPENCE, J. T. (Univ. of Texas, Austin, Tex. 78712). Effects of blank versus noninformative feedback and "right" and "wrong" on response repetition in paired-associate learning: A reanalysis and reinterpretation. Journal of Experimental Psychology, 1972, 94, 146-148.

TELL, P. M. (Florida Tech. Univ., Orlando, Fla. 32816), \& SCHULTZ, W. Retroactive interference as a function of degree of interpolated learning and instructional set. Journal of Experimental Psychology, 1972, 94, 337-339.

Verbal Discrimination Learning

BRUDER, G. (State Univ. of New York, Buffalo, N.Y. 14226), \& SILVERMAN, W. Effects of semantic and phonetic similarity on verbal recognition and discrimination. Journal of Experimental Psychology, 1972, 94, 314-320.

PAUL, H. (Hofstra Univ., Hemstead, L.I., N.Y. 11550). Verbal discrimination learning: A distinction between frequency and "frequency-rule" effects. Journal of Experimental Psychology, 1972, 94, 343-344.

SCHULZ, L. S. (Coll. of Ed., Univ. of Delaware, Newark, Del. 19711), \& LOVELACE, E. A. Interpair acoustic and formal similarity in verbal discrimination learning.
Journal of Experimental Psychology, 1972, 94, 295-299.

ROWE, E. J. (Mem. Univ. of Newfoundland, St. John's, Nfld., Canada). Imagery and repetition instructions in verbal discrimination learning as a function of lag. Psychonomic Science, 1972, 27, 363-364.

Word \& Sentence Learning

ANDERSON, R. C. (Trng. Rsch. Lab., 226 Ed. Bldg., Univ. of Illinois, Urbana, Ill. 61801), \& KULHAVY, R. W. Imagery and prose learning. Journal of Educational Psychology, $1972,63,242-243$.

CAPLAN, D. (Dept. of Linguistics, Massachusetts Inst. of Tech., Cambridge, Mass. 02139). Clause boundaries and recognition latencies for words in sentences. Perception \& Psychophysics, 1972, 12, 73-76.

CORBALLIS, M. C. (McGill Univ., Montreal, P.Q., Canada), KIRBY, J., \& MILLER, A. Access to elements of a memorized list. Journal of Experimental Psychology, 1972, 94, 185-190.

CROUSE, J. H. (Coll. of Ed., Univ. of Delaware, Newark, Del. 19711), \& IDSTEIN, P. Effects of encoding cues on prose learning. Journal of Educational Psychology, 1972, 63, 309-313.

MacKENZIE, D. J. (Stanford Univ., Stanford, Calif. 94305), \& ATKINSON, R. C. Incidental learning of words used in a memory scanning task. Psychonomic Science, 1972, 27, 317-320.

MUISE, J. G. (Univ. of Moncton, Moncton, N.B., Canada), Le BLANC, R. S., \& JEFFREY, C. $J$. Comparison of redundancy of French and English through use of a regular finite Markov process. Perceptual \& Motor Skills, 1972, 34, 712-714.

MYROW, D. L., \& ANDERSON, R. C. (Trng. Rsch. Lab., 226 Ed. Bldg., Univ. of Illinois, Urbana, Ill. 61801). Retroactive inhibition of prose as a function of the type of test. Journal of Educational Psychology, 1972, 63, 303-308.

SASSON, R. Y. (Laboratoire de Psychologie Expèrimentale, 28, rue Serpente, Paris 6e, France), \& FRAISSE, P. Images in memory for concrete and abstract sentences. Journal of Experimental Psychology, 1972, 94, 149-155.

SCHULTZ, C. B. (Dept. of Ed., Trinity Coll., Hartford, Conn. 06106), \& DI VESTA, F. J. Effects of passage organization and note taking on the selection of clustering strategies and on recall of textual materials. Journal of Educational Psychology, 1972, 63, 244-252.

UNDERWOOD, B. J. (Northwestern
Univ., Evanston, Ill. 60201), PATTERSON, M., \& FREUND, J. $S$. Recognition and number of incorrect alternatives presented during learning. Journal of Educational Psychology, 1972, 63, 1-7.

WEIST, R. M. (Univ. of Nebraska-Lincoln, Lincoln, Nebr. 68508), \& DOLEZAL, J. The effect of violating phrase structure rules and selectional restrictions on TEP patterns. Psychonomic Science, 1972, 27, 355-356.

\section{REINFORCEMENT}

ANDERSON, R. C. (Trng. Rsch. Lab., 226 Ed. Bldg., University of Illinois, Urbana, Ill. 61801), KULHAVY, R. W., \& ANDRE, T. Conditions under which feedback facilitates learning from programmed lessons. Journal of Educational Psychology, 1972, $63,186-188$.

CHEYNE, J. A. (Univ. of Waterloo, Ont., Canada). Direct and vicarious reinforcement: $A$ note on punishment and negative instances. Journal of Educational Psychology, $1972,63,63-68$.

D'AMICO, A., \& VINEY, W. (Colorado State Univ., Fort Collins, Colo. 80521). Effects of response force and intertrial interval on extinction in children. Journal of Comparative \& Physiological Psychology, 1972, 80, 349-353.

FAVELL, J. E. (Western Carolina Ctr., Morganton, N.C. 28655), \& FAVELL, J. E. Control of preference in children by conditioned positive reinforcement. Journal of the Experimental Analysis of Behavior, 1972, 18, 107-112.

KELLER, H. R. (Univ. of South Carolina, Columbia, S.C. 29208), \& PARKER R. K. Effects of event schedules and external incentives on discrimination of acquisition and extinction phases of learning under state instructions. Psychological Reports, 1972, 30, 839-845.

PARKER, R. K., \& KELLER, H. R. (Univ. of South Carolina, Columbia, S.C. 29208). Effects of event schedules, event values, and instructions on ability of college males to discriminate acquisition from extinction. Psychological Reports, 1972, 30, 959-965.

POPPEN, R. (Rehab. Inst., Southern Illinois Univ., Carbondale, Ill. 62901). Effects of concurrent schedules on human fixed-interval performance. Journal of the Experimental Analysis of Behavior, 1972, 18, 119-127.

ROTHBERG, C. (Dept. of Ed. Fdtns., Univ. of New Mexico, Albuquerque, N. Mex. 87106), \& HARRIS, M. B. "'Right,", "wrong,", and 
discrimination learning in children. Journal of Genetic Psychology, 1972, 120, 275-286.

SHIPLEY, C. R., BARON, A. (Univ of Wisconsin-Milwaukee Milwaukee, Wis. 53201), \& KAUFMAN, A. Effects of timeout from one reinforcer of human behavior maintained by another reinforcer. Psychological Record, 1972, 22, 201-210.

SPENCE, J. T. (Univ. of Texas, Austin, Tex. 78712). Effects of blank versus noninformative feedback and "right" and "wrong" on response repetition in paired-associate learning: $A$ reanalysis and reinterpretation. Journal of Experimental Psychology, 1972, 94, 146-148.

STRANG, H. R. (Univ. of Virginia, Charlottesville, Va. 22204). Task definition and immediate knowledge of results in monitoring performance. Perceptual \& Motor Skills, 1972, 34, 825-826.

STURGES, P. T. (Chico State Coll., Chico, Calif. 95926). Effect of instructions and form of informative feedback on retention of meaningful material. Journal of Educational Psychology, 1972, 63, 99-102.

SUBOSKI, M. Г. (Queen's Univ., Kingston, Ont., Canada), \& LITNER, J. Partial reinforcement and instructional set in discrimination conditioning of the eyelid response. Canadian Journal of Psychology, 1972, 26, 117-126. WAITE, W. W. (Bingham County Multi-District Program for Handicapped Children, Route 2, Box 249A, Wilson Bldg., Blackfoot, Idaho 83221), \& OSBORNE, J. G. Sustained behavioral contrast in children. Journal of the Experimental Analysis of Behavior, $1972,18,113-117$.

WEINSTEIN, L. (c/o John Babchuk, Box 308, Willingdon, Alta. Canada). Negative incentive contrast in humans with partial versus continuous reinforcement and repeated reductions in reward. Journal of Experimental Psychology, 1972, 94, 210-215.

WEIR, M. W. (Univ. of Illinois, Champaign, Ill. 61820). Probability performance: Reinforcement procedure and number of alternatives. American Journal of Psychology, 1972, 85, 261-270.

WHITE, R. M., JR. (Miami Univ., Oxford, Ohio 45056). Relationship of performance in concept identification problems to type of pretraining problem and response-contingent postfeedback intervals. Journal of Experimental Psychology, 1972, 94, 132-140.

WHITE, R. M., JR. (Miami Univ., Oxford, Ohio 45056), \& SCHMIDT, S. W. Preresponse intervals versus postinformative feedback intervals in concept identification. Journal of Experimental Psychology, 1972, 94, 350-352

\section{HUMAN MEMORY}

CORBALLIS, M. C. (McGill Univ., Montreal, P.Q., Canada), KIRBY, J., \& MILLER, A. Access to elements of a memorized list. Journal of Experimental Psychology, 1972, 94, 185-190.

DECKERS, L. (Ball State Univ., Muncie, Ind. 47306). Unlearning as a function of the number of a cquired interpolated responses. Psychonomic Science, 1972, 28, 109-110.

FREUND, J. S. (Univ. of Arkansas, Fayetteville, Ark. 72701), \& JOHNSON, J. W. Changes in memory attribute dominance as a function of age. Journal of Educational Psychology, 1972, 63, 386-389

GUMMERMAN, K. (Univ. of Texas, Austin, Tex. 78712), GRAY, C. R., \& WILSON, J. M. An attempt to assess eidetic imagery objectively. Psychonomic Science, 1972, 28, 115-118.

HAMILTON, P. (Univ. of Stirling, Stirling, Scotland), HOCKEY, G. R.
J., \& QUINN J. G. Information selection, arousal and memory. British Journal of Psychology, 1972, 63, 181-189.

HICKS, J. A., III (213-B Millbrook Rd., Raleigh, N.C. 27609). Effects of number of alternative states and number of channels on the monitoring of multichannel displays. Journal of Experimental Psychology, 1972, 94, 348-350.

JACOBY, L. L. (Iowa State Univ., Ames, lowa 50010). Context effects on frequency judgments of words and sentences. Journal of Experimental Psychology, 1972, 94, 255-260.

JOHNSON, R. E. (SCC "G," Purdue Univ., Lafayette, Ind. 47907). Associative labeling and retention. Psychological Record, 1972, 22, 237-239.

LIBKUMAN, T. (Central Michigan Univ., Mt. Pleasant, Mich. 48858), \& FRIEDRICH, D. Threshold measures of sensory register storage (perceptual memory) on normals and retardates. Psychonomic Science, 1972, 27, 357-358.

MARTIN, D. W. (New Mexico State Univ., Las Cruces, N. Mex. 88001), \& RICHARDS, E. Locus of selectivity in a visual memory task using a color value indicator. Perception \& Psychophysics, 1972, 12, 65-68.

SASSON, R. Y. (Laboratoire de Psychologie Expèrimentale, 28, rue Serpente, Paris 6e, France), \& FRAISSE, P. Images in memory for concrete and abstract sentences. Journal of Experimental Psychology, 1972, 94, 149-155.

SIEGEL, W. (Univ. of Western Ontario, London 72, Ont., Canada). Memory effects in thymethod of absolute judgment. Journal of Experimental Psychology, 1972, 94, 121-131.

\section{LONG-TERM MEMORY}

AUSUBEL, D. P. (Grad. Sch., City Univ, of New York, New York, N.Y. 10010), \& SCHWARTZ, F. G. The effects of a generalizingparticularizing dimension of cognitive style on the retention of prose material. Journal of General Psychology, 1972, 87, 55-58.

GROEN, G. J. (Carnegie-Mellon Univ., Pittsburgh, Pa. 15213), \& PARKMAN, J. M. A chronometric analysis of simple addition. Psychological Review, 1972, 79, 329-343.

ROLLINS, H. A. (Emory Univ., Atlanta, Ga. 30329). Serial position effects in simultaneous bisensory memory. Journal of Experimental Psychology, 1972, 94, 162-167.

STURGES, P. T. (Chico State Coll., Chico, Calif. 95926). Effect of instructions and form of informative feedback on retention of meaningful material. Journal of Educational Psychology, 1972, 63, 99-102.

WEIST, R. M. (Univ. of Nebraska, Lincoln, Nebr. 68508), \& CRAWFORD, C. Phonological and semantic representations of words, compartments of memory, and rehearsal. Psychonomic Science, 1972, 28, 106-108.

\section{Recognition Memory}

BRUDER, G. (State Univ. of New York, Buffalo, N.Y. 14226), \& SILVERMAN, W. Effects of semantic and phonetic similarity on verbal recognition and discrimination. Journal of Experimental Psychology, 1972, 94, 314-320.

SNODGRASS, J. G. (New York Univ., University Heights, Bronx, N.Y. 10453), VOLVOVITZ, R., \& WALFISH, E. R. Recognition memory for words, pictures, and 
words + pictures. Psychonomic Science, 1972, 27, 345-347.

UNDERWOOD, B. J. (Northwestern Univ., Evanston, Ill. 60201). Word recognition memory and frequency information. Journal of Experimental Psychology, 1972, 94 . 276-283.

UNDERWOOD, B. J. (Northwestern Univ., Evanston, Ill. 60201), PATTERSON, M., \& FREUND, J. S. Recognition and number of incorrect alternatives presented during learning. Journal of Educational Psychology, 1972, 63, 1-7.

WYANT, S., BANKS, W. P. (Pomona Coll., Claremont, Calif. 91711), BERGER, D., \& WRIGHT, P. W. Verbal and pictorial similarity in recognition of pictures. Perception \& Psychophysics, 1972, 12, $151-153$

\section{Recall}

BARCLAY, A. (St. Louis Univ., St. Louis, Mo, 63103), YATER, A., \& WECHSLER, D. Preliminary investigation of the visuo-motor recall test. Perceptual \& Motor Skills, 1972, 34, 867-872.

BELCHER, M. M. (West Virginia Wesleyan Coll., Buckhannon, W. Va. 26201 ), BONE, R. N., \& MONTGOMERY, D. D. Rigidity and dream recall. Psychological Reports, $1972,30,858$.

CHOVAN, W. L. (Western Carolina Univ., Cullowhee, N.C. 27823). Conceptual organization of recall in an object arrangemen task with deaf and hearing children. Perceptual \& Motor Skills, 1972, 34, 742 .

LEY, R. (State Univ. of New York, Albany, N.Y. 12203), \& LOCASCIO, D. Study time, recall time, meaningfulness, and recognition latency in paired-associate learning. Psychonomic Science, 1972, 28, 88-90.

PALMER, M. B. (Univ. of Northern Colorado, Greenley, Colo. 80631). Effects of categorization, degree of bilingualism, and language upon recall of select monolinguals and bilinguals. Journal of Educational Psychology, 1972, 63, 160-164.

PHILIPCHALK, R. P. (St. Thomas Univ., Fredericton, N.B., Canada). Thermaticity, abstractness, and the long-term recall of connected discourse. Psychonomic Science, 1972, 27, 361-362.

SCHULTZ, C. B. (Dept. of Ed., Trinity Coll., Hartford, Conn. 06106), \& DI VESTA, F. J. Effects of passage organization and note taking on the selection of clustering strategies and on recall of textual materials. Journal of Educational
Psychology, 1972, 63, 244-252.

SCHWARTZ, R. M. (Univ. of British Columbia, Vancouver, B.C. Canada), \& HUMPHREYS, M. S Examinations of the category-recall function. American Journal of Psychology, 1972, 85, 189-200.

ZACKS, R. T. (Michigan State Univ., East Lansing, Mich. 48823). Long-term retention after acquisition under different conditions of practice. Journal of Experimental Psychology, 1972, 94, 340-342.

\section{Free Recall}

BALSER, E. (Div. of Language \& Lit., Fairmont State Coll., Fairmont, W. Va. 26554). The free recall and category clustering of factual material presented in complex sentences. Psychonomic Science, 1972, 27, 327-328.

ELMES, D. G. (Washington \& Lee Univ., Lexington, Va. 24450) GREENER, W. I., \& WILKINSON, W. C. Free recall of items presented a f $t$ e $r \quad m$ a s s e d - a n d distributed-practice items. American Journal of Psychology, 1972, 85, 237-240.

JOHNSON, M. K. (State Univ. of New York, Stony Brook, N.Y. 11790). Organizational units in free recall as a source of transfer. Journal of Experimental Psychology, 1972, 94, 300-307.

PELLEGRINO, J. W. (Univ. of Colorado, Boulder, Colo. 80302). A FORTRAN IV program for analyzing higher-order subjective organization units in free recall learning. Behavior Research Methods \& Instrumentation, 1972, 4, 215-217.

TZENG, O. J. L. (201 Soc. Sci. Bldg., Pennsylvania State Univ., University Park, Pa. 16802), SNYDER, H. I., \& HUNG, D. L. The effects of overt intralist retrieval on subsequent free recall. Psychonomic Science, 1972, $28,103-105$.

\section{SHORT-TERM MEMORY}

BARTZ, W. H. (Iowa State Univ., Ames, Iowa 50010). Rehearsal strategies and partial recall in immediate memory. Journal of Experimental Psychology, 1972, 94, 141-145.

CONRAD, R. (Nuffield Hearing \& Speech Ctr., 330 Grays Inn Rd., Lond on, W.C.1, England). Short-term memory in the deaf: A test for speech coding. British Journal of Psychology, 1972, 63, 173-180.

DERKS, P. L. (Coll. of William \& Mary, Williamsburg, Va. 23185), GOALDER, J., \& SCHULZ, L. S. Im mediate memory for simultaneously presented items: The effects of search for a target item. Psychonomic Science, 1972, 28, 100-102.

HAYES, C. S. (Child Dev. Clin, Univ. Hosp. Sch., Iowa City, Iowa 52240 ), \& ROUTH, D. K. Short-term memory in normals and retardates as a function of stimulus intensity and recall interval: A test of Ellis's $S_{t}$ theory. Psychological Reports, 1972, 30, 831-836.

McLAUGHLIN, J. P. (Univ, of Delaware, Newark, Del. 19711), MASTERSON, F. A., \& HARRMANN, D. J. Pattern redundancy and detection in very short-term memory. Perception \& Psychophysics, 1972, 12, 205-208.

MEUDELL, P. R. (Univ. of Manchester, Manchester M13 9PL, England). Short-term visual memory: Comparative effects of two types of distraction on the recall of visually presented verbal and nonverbal material. Journal of Experimental Psychology, 1972, 94, 244-247.

MURDOCK, B. B., JR. (Univ. of Toronto, Toronto 181 , Ont., Canada), \& DUFTY, P. O. Strength theory and recognition memory. Journal of Experimental Psychology, 1972, 94, 284-290.

WOLK, S. (Temple Univ., Philadelphia, $\mathrm{Pa} .19122), \&$ SNELBECKER, G. E. Acoustical confusion, short-term memory, and latency of recall. Journal of General Psychology, 1972, 87, 77-83.

\section{TRANSFER}

EARHARD, B. (Dalhousie Univ., Halifax, N.S., Canada), FRIED, C.-A., \& CARLSON, G. Interference, overlearning, and anticipation time. Journal of Experimental Psychology, 1972, 94, 345-347.

JOHNSON, M. K. (State Univ. of New York, Stony Brook, N.Y. 11790). Organizational units in free recall as a source of transfer. Journal of Experimental Psychology, 1972, 94, 300-307.

MYROW, D. L., \& ANDERSON, R. C. (Trng. Rsch. Lab., 226 Ed. Bldg., University of Illinois, Urbana, Ill. 61801). Retroactive inhibition of prose as a function of the type of test. Journal of Educational Psychology, 1972, 63, 30-308.

TELL, P. M. (Florida Tech. Univ., Orlando, Fla. 32816), \& SCHULTZ, W. Retroactive interference as a function of degree of interpolated learning and instructional set. Journal of Experimental Psychology, 1972, 94, 337-339. 


\section{HUMAN THINKING}

AUSUBEL, D. P. (Grad. Sch., City Univ. of New York, New York, N.Y. 10010), \& SCHWARTZ, F. G. The effects of a generalizingparticularizing dimension of cognitive style on the retention of prose material. Journal of General Psychology, 1972, 87, 55-58.

FRICK, J. W. (Pennsylvania State Univ., University Park, Pa. 16802), \& COFER, C. N. Berlyne's demonstration of epistemic curiosity: An experimental re-evaluation. British Journal of Psychology, 1972, 63, 221-228.

KESSEL, F. S. (Univ. of Cape Town, Cape Town, South Africa). Imagery: A dimension of mind rediscovered. British Journal of Psychology, 1972, 63, 149-162.

STRATTON, R. P. (Univ. of Kentucky, Lexington, Ky. 40506), \& BROWN, R. Improving creative thinking by training in the production and/or judgment of solutions. Journal of Educational Psychology, 1972, 63, 390-397.

\section{VERBAL PROCESSES}

GIANUTSOS, R. (Adelphi Univ., Garden City, N.Y. 11530). The psychoacoustic reality of words. Psychonomic Science, 1972, 28, 91-93.

MORRIS, P. E. (Univ. of Exeter, Exeter, England), \& REID, R. L. Canadian and British ratings of the imagery values of words. British Journal of Psychology, 1972, 63, 163-164.

SCOTT, R. (Univ. of Northern Iowa, Cedar Falls, Iowa 50613), \& SATTEL, L. Perception and language: A German replication of the Piaget-Inhelder position. Journal of Genetic Psychology, 1972, 120, 203-210.

STARK, K. (Inst. of Human Lrng., Univ. of California, Berkeley, Calif. 94720 ). Synonym responses to 100 free association stimuli. Psychonomic Monograph Supplements, 1972, 4(16, Whole No. 64).

STRATTON, R. P. (Univ. of Kentucky, Lexington, Ky. 40506), \& WATHEN, K. E. Thinking of a word under instructional constraints. Psychonomic Science, 1972, 28, 97-99.

\section{PROBLEM SOLVING}

EVANS, J. St. B. T. (City of London Polytech., London, England). Interpretation and matching bias in a reasoning task. Quarterly Journal of Experimental Psychology, 1972, 24, 193-199.

EVANS, J. St. B. T. (City of London Polytech., London, England). Reasoning with negatives. British Journal of Psychology, 1972, 63, 213-219.

GOODWIN, R. Q. (Sch. of Cultural \& Community Studies, Univ. of Sussex, Brighton, England), \& WASON, P. C. Degrees of insight. British Journal of Psychology, 1972, 63, 205-212.

JONES, M. R. (Ohio State Univ., Columbus, Ohio 43210), \& ERICKSON, J. R. A demonstration of complex rule learning in choice prediction. American Journal of Psychology, 1972, 85, 249-260.

PIRYOV, G. D. (Bulgarian Acad. of Sci., Sofia, Bulgaria). Hypothesis in learning to solve technical problems. Studia Psychologica, 1972, XIV, 124-127.

SCANDURA, J. M. (Grad. Sch. of Ed., Univ. of Pennsylvania, Philadelphia, $\mathrm{Pa}$. 19104). What is a rule? Journal of Educational Psychology, 1972, 63, 179-185.

SCHULTZ, C. B. (Dept. of Ed. Psychol., Pennsylvania State Univ., University Park, Pa. 16802), \& DI VESTA, F. J. Effects of expert endorsement of beliefs on problem-solving behavior of high and low dogmatics. Journal of Educational Psychology, 1972, 63, 194-201.

\section{CONCEPTS}

ARNBERG, P. W. (Univ. of Stockholm, Stockholm, Sweden), \& RYDBERG, S. Effects of overlearning on attention to position in concept learning. Psychonomic Science, 1972, 28, 94-96.

BYNNER, J. (Open Univ., Walton Hall, Bletchley, Buckinghamshire, England), \& ROMNEY, D. A method for overcoming the problem of concept-scale interaction in semantic differential research. British Journal of Psychology, 1972, 63, 229-234.

GRIPPIN, P. C. (State Univ. of New York, Albany, N.Y. 12203), \& OHNMACHT, F. W. Relationship of field independence and dogmatism with an hierarchically arranged concept learning task. Perceptual \& Motor Skills, 1972, 34, 983-986.

HAYGOOD, R. C. (Arizona State Univ., Tempe, Ariz. 85281), FISHBEIN, H. D., \& PINZKA, C. F. A mathematical model for the wholist strategy in concept identification. Psychonomic Science, 1972, 27, 321-324.

LAUGHLIN, P. R. (Univ. of Illinois Champaign, Ill. 61820). Selection versus reception concept-attainment paradigms for individuals and cooperative pairs. Journal of Educational Psychology, 1972, 63, 116-122.

LEVY, P. (Univ. of Birmingham, Birmingh am, England). Concept-scale interaction in semantic differential research: Solutions in search of a problem. British Journal of Psychology, 1972, 63, 235-236.

McKINNEY, J. D. (Frank Porter Graham Child Dev. Ctr., Univ. of North Carolina, Chapel Hill, N.C. 27514). Developmental study of the acquisition and utilization of conceptual strategies. Journal of Educational Psychology, 1972, 63, 22-31.

O'MALLEY, J. J. (Ohio Univ., Athens, Ohio 45701). Amount of training, percentage of reinforcement, and perseveration in concept learning. Journal of General Psychology, 1972, 87, 105-110.

PISHKIN, V. (VA Hosp., 921 N.E. 13th St., Oklahoma City, Okla. 73104). Concept identification with mnemonic cues as a function of children's sex and age. Journal of Educational Psychology, 1972, 63, 93-98.

SANDERS, N. M. (Dept. of Ed. Psychol., Pennsylvania State Univ., University Park, Pa. 16802), DI VESTA, F. J., \& GRAY, G. S. Effects of concept instance sequence as a function of stage of learning and learner strategy. Journal of Educational Psychology, $1972,63,235-241$.

SCHULTZ, R. F., JR. (Univ. of Utah, Salt Lake City, Utah, 84112), \& DODD, D. H. Intradimensional variability in concept identification: A replication, extension, and partial clarification of the Haygood, Harbert, and Omlor findings. Journal of - Experimental Psychology, 1972, 94, 321-325.

WHITE, R. M., JR. (Miami Univ., Oxford, Ohio 45056). Relationship of performance in concept identification problems to type of pretraining problem and response-contingent postfeedback intervals. Journal of Experimental Psychology, 1972, 94, 132-140.

WHITE, R. M., JR. (Miami Univ., Oxford, Ohio 45056). Effects of some pretraining variables on concept identification. Journal of Experimental Psychology, 1972, 94, 198-205.

WHITE, R. M., JR. (Miami Univ., Oxford, Ohio 45056)., \& SCHMIDT, S. W. Preresponse intervals versus postinformative 
feedback intervals in concept identification. Journal of

Experimental Psychology, 1972, 9.4, 350-352.

\section{HUMAN DEVELOPMENT}

BRAINE, L. G. (New York Univ., New York, N.Y. 10003 ). A developmental analysis of the effect of stimulus orientation on recognition. American Journal of Psychology, 1972, 85, 157-188.

FREUND, J. S. (Univ. of Arkansas, Fayetteville, Ark. 72701), \& JOHNSON, J. W. Changes in memory attribute dominance as a function of age. Journal of Educational Psychology, 1972, 63, 386-389.

McKINNEY, J. D. (Frank Porter Graham Child Dev. Ctr., Univ. of North Carolina, Chapel Hill, N.C. 27514). Developmental study of the acquisition and utilization of conceptual strategies. Journal of
Educational Psychology, 1972, 63, 22-31.

PETERS, R. W. (Univ. of Georgia, Athens, Ga. 30601$)$, \& TORRANCE, E. P. Dyadic interaction of preschool children and performance on a construction task. Psychological Reports, 1972, 30, 747-750.

PISHKIN, V. (VA Hosp., 921 . N.E. 13th St., Oklahoma City, Okla. 73104). Concept identification with mnemonic cues as a function of children's sex and age. Journal of Educational Psychology, 1972, 63, 93-98. 